\title{
Economic and environmental sustainability dimensions of a fashion supply chain: A quantitative model
}

\author{
Eleonora Bottani ${ }^{\mathrm{a} *}$ (D), Letizia Tebaldi ${ }^{\mathrm{a}}$ (D), Isabella Lazzari $^{\mathrm{b}}$, Giorgia Casella ${ }^{\mathrm{a}}$ \\ aDepartment of Engineering and Architecture, University of Parma, Parma, Italy

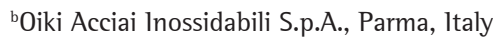 \\ *eleonora.bottani@unipr.it
}

\begin{abstract}
Paper aim: The paper presents a model to assess the economic and the environmental sustainability dimensions of a fashion supply chain and tests it on a company.

Originality: The gap intended to fill is the lack of models in this context having this purpose, and, in general, the necessity to develop models and metrics allowing to quantitatively assess the economic and environmental dimensions of supply chains.

Research method: The fashion supply chain has been divided into five processes. Hence, an analytic model was developed by considering the total costs incurring in each process (economic evaluation), and the annual kilograms of $\mathrm{CO}_{2}$ emitted (environmental perspective). The model was then applied to a case study. Data was obtained from interviews with the management.
\end{abstract}

Main findings: Results show that from the economic perspective supply impacts the most, while from the environmental one the most polluting activity is production.

Implications for theory and practice: The model is easy to apply and to understand and allows to identify the activities in the supply chain where the majority of costs/emissions are generated. It is therefore expected to be useful for undertaking operational decisions aimed at decreasing the economic or environmental impact of a fashion supply chain.

Keywords

Textile industry. Case study. Sustainable supply chain. Analytic model.

How to cite this article: Bottani, E., Tebaldi, L., Lazzari, 1.\& Casella, G. (2020). Economic and environmental sustainability dimensions of a fashion supply chain: A quantitative model. Production, 30, e20190156. https://doi.org/10.1590/01036513.20190156

Received: Dec. 20, 2019; Accepted: June 17, 2020.

\section{Introduction}

The term sustainability first appeared in 1972 in Stockholm, during the first United Nations Conference on environmental issues, and from that moment it never left and it strongly affected the direction of research of the following years. Exploration in this context has exponentially grown; only two years ago a simple Google search with this keyword produced 164,000,000 results in 0.48 seconds (Colombo \& Alves, 2017) while now it returns $1,280,000,000$ in 0.42 seconds, a number nearly eight times higher demonstrating the huge spread, the popularity of the theme and the ease of access to information.

In the face of realities such as the climate change, the depletion of resources, the increase in pollution and the various accidents occurred in the past, authorities, companies and consumers were forced to act in that direction: the first by drawing up laws and regulations limiting, for instance, emissions; the second by complying these regulations and adopting major innovations so that they could operate in a responsible way; the last by demanding eco-friendly products and services, and rewarding those companies which expend themselves for sustainability. 
In the business context, the integration of economic, environmental and social objectives generates the concept of corporate sustainability (CS), pursued through the adoption of sustainable business strategies (Aloise \& Macke, 2017). CS corresponds to the commitment of companies to raise their productivity, improve their products and management methods contributing at the same time to the preservation of the environment (Gonçalves de Azevedo et al., 2016), and nowadays taking care of these elements has become a real competitive advantage. Recently, indeed, more than 14,000 global public companies (compared to less than 100 companies a decade ago) disclosed their financial economic sustainability performance (ESP) and non-financial environmental, social, ethical and governance (ESEG) sustainability performance information (Rezaee, 2018) to confirm their actions.

In general, as they say, "unity is strength": this is the reason why these actions affect the whole supply chain (SC) that companies belong to, rather than the single firm. Indeed, it was demonstrated that collaborations among the various actors of a SC have a positive impact on greater environmental and economic performances (Tebaldi et al., 2018), and another certainty is that sustainable supply chains are the developmental trend for economics (Hou et al., 2019).

Supply chain models were traditionally designed to minimize total costs without taking into account their harmful emissions; in recent studies this last issue has been included (Elhedhli \& Merrik, 2012), and this also led to introduce the term sustainable supply chain management (SSCM), i.e. the management of material, information and capital flows as well as cooperation among companies along the supply chain while taking goals from all three dimensions of sustainable development into account which are derived from customer and stakeholder requirements (Seuring \& Müller, 2008).

Sustainable solutions, as already stressed, can be achieved through integrating the economic, environmental and social dimensions, the so-called triple bottom line (TBL) approach or also 3P formulation of people, planet and profit (Elkington, 2004), which have overcome the previous single bottom line perspective that only focused on financial objectives (Oelze at al., 2018). The economic sustainability is defined as the ability to generate durable growth of economic indicators, notably the ability to generate income and employment for the population livelihood; the environmental sustainability refers to preserving the natural ecosystem by reducing polluting emissions and waste production, and the social sustainability is defined as the ability to ensure equity in quality of life and human well-being conditions, regardless of class and gender (Capone et al., 2016). Metaphorically, Teuteberg \& Wittstruck (2010) proposed the concept of "House of Sustainable Supply Chain", built on the three columns of the TBL approach, meaning they are basic and fundamental pillars to retain the house in balance. The recent work by Babu \& Mohan (2018) added a fourth dimension, due to culture and governance, which can significantly affect sustainability, generating the new concept of quadruple bottom line. Clearly, the challenge is to achieve a balance between all these dimensions.

On the basis of the considerations above, there is an increased need for individuals, organizations, and society to develop models, metrics ad tools to measure a company's sustainability performance (Singh et al., 2009; Seuring \& Gold, 2013). Sustainability assessment, indeed, provides the managers with an evaluation of the global (or local) company's performance, and assists them in determining the actions to undertake to make the system more sustainable (Kates et al., 2001). Sustainability performance measurement requires a systematic approach, able to take into account all aspects of an enterprise sustainability (Searcy, 2016). In line with this, the focus of this paper is thus to propose an analytic model for sustainability evaluation.

It is worth mentioning that there are some issues that should be solved for a consistent evaluation of the company's sustainability (Bottani et al., 2017). To be more precise, a main point is that all the aspects relevant for sustainability evaluation should be first identified and expressed in a quantitative way; this is not easy for the social sustainability perspective, which often lacks specific and quantitative indexes (Colla et al., 2008). As we focused on providing a quantitative assessment, the social perspective was not included in the proposed analytic approach.

The approach presented therefore focuses on the quantitative evaluation of the economic and environmental sustainability of a supply chain and was tailored for the specific case of the fashion industry. Indeed, sustainability in this context is still poorly explored in literature, despite its relevance (Boström \& Micheletti, 2016). To enable a detailed evaluation, the fashion supply chain was first divided into its main processes, which were derived from the analysis of the literature; for each process, the economic/environmental sustainability is evaluated.

To test its effectiveness and ease of usage, the model was applied for the evaluation of the economic and environmental sustainability of the supply chain processes of a company based in the North of Italy, called Company A and operating in the fashion industry.

The remainder of the manuscript is as follows. Section 2 briefly presents the main findings about sustainability in the fashion supply chain context, with reference to the existing literature. Section 3 outlines the methodology and the development of the model, while section 4 deals with application of the proposed approach to the case 
study. To show the evaluation of both the economic and environmental aspects, at the same time avoiding excessive length of the paper, this section proposes the full details of the application focusing on some processes only. Nonetheless, the case study was carried out in full; hence, the numerical outcomes are provided for all supply chain processes. Discussion, conclusions and suggestions for future research are finally presented in section 5.

\section{Sustainability in the fashion supply chain}

Sustainability in the fashion industry has recently gained attention but, even so, has not yet been properly deepen (Yang et al., 2017); this is the reason why the choice has fallen on this specific context. Achieving sustainable practices in the fashion and textile industries is difficult in practice, since their supply chain are long and complex (Shim et al., 2018); at the same time, however, it is essential, as the fashion industry is among the world's most polluting industries (Boström \& Micheletti, 2016). There is little doubt that considering the pillars of sustainability is critical to company's success (Choi et al., 2018). Interesting issues are given by Karaosman et al. (2016), who reviewed the existing literature on the integration of sustainability in fashion operations including the supply chain level, confirming that the implementation of sustainable practices can positively influence the supply chain itself and the firms' performance. Desore \& Narula (2018) also gave an overview of corporate response towards sustainability issues in the fashion context, showing that companies are taking active steps to improve their environmental performance, even if this mainly happens in developed countries.

Looking at the different processes of a fashion supply chain, some previous studies analyze sustainable solutions for the production of raw materials. For instance, Radhakrishnan (2017) dealt with a green cotton production, from its cultivation to its real industrialization; Sanches et al. (2015), instead, made an interesting comparative study on the characteristics of knitted fabrics produced from organic cotton, lyocell and soybean protein fiber. The results of this study demonstrate that these materials are less impactful for the environment, being at the same time adequate for textile applications. Another critical element at the supply stage is the vendor selection process, in which the focal company of the fashion supply chain may be involved. Interesting contributions on this topic have been provided by Amindoust \& Saghafinia (2017) who developed a model for a sustainable selection, and by Winter \& Lasch (2016) who presented environmental (e.g. end-of-pipe control, namely wastewater treatment systems or eco-friendly materials) and social (e.g. no child labor, working hours, no forced labor or discrimination and many others) criteria to be included in purchasing practices within the fashion context. As far as the transformation into finished products, most of the proposed sustainable process innovations deal with the usage of solvents replacing water (e.g. for bleaching), accordingly related to chemical issues (see for instance Eren et al. (2018) or Hussain \& Wahab (2018)). The logistics aspect is an interesting topic which is absolutely widespread and affirmed within the context of sustainable supply chain (SSC); indeed, this kind of activities are likely to generate undesired "byproducts" such as inefficient/excessive use of fossil burning fuels or carbon dioxide emissions (Bottani et al., 2015); even if to the best of authors' knowledge there are no studies specifically related to the fashion SC, there is a plethora of previous works dealing with possible ways for optimizing transports and inventories, from which both environmental and economic benefits can derive. Recently, it is worth mentioning that in this field also the use of Radio Frequency Identifications systems has been recognized as leading to green benefits (Denuwara et al., 2019).

Finally, several studies encourage reverse logistics activities and closed-loop supply chains; that is the case with works by lewis et al. (2017) who promote solutions for production starting from second-hand clothing, or by Beh et al. (2016), who presented a business model for second-life retailing; but many other could been mentioned as far as this precious recovery.

Despite that, in the available literature there is no evidence of studies providing a model able to quantitatively assess both the economic and environmental dimensions of fashion supply chains: this is the gap intended to be filled in the present manuscript.

\section{Methodology: Analytic modelling and development}

\subsection{Model overview}

From the analysis of the existing literature and the existing models for sustainability assessments, a set of five key processes was identified for the fashion supply chain, namely: (1) supply, (2) warehouse, (3) production, (4) distribution and (5) reverse logistics (Figure 1). This latter process has been included in the mapping of the fashion supply chain as the recent orientation is that reverse logistics has to be fully considered as a part of the supply chain (Lewis et al., 2017; Beh et al., 2016). The studies by Chen \& Andresen (2014), Mota et al. (2015) 


\section{Fashion Supply Chain Processes}

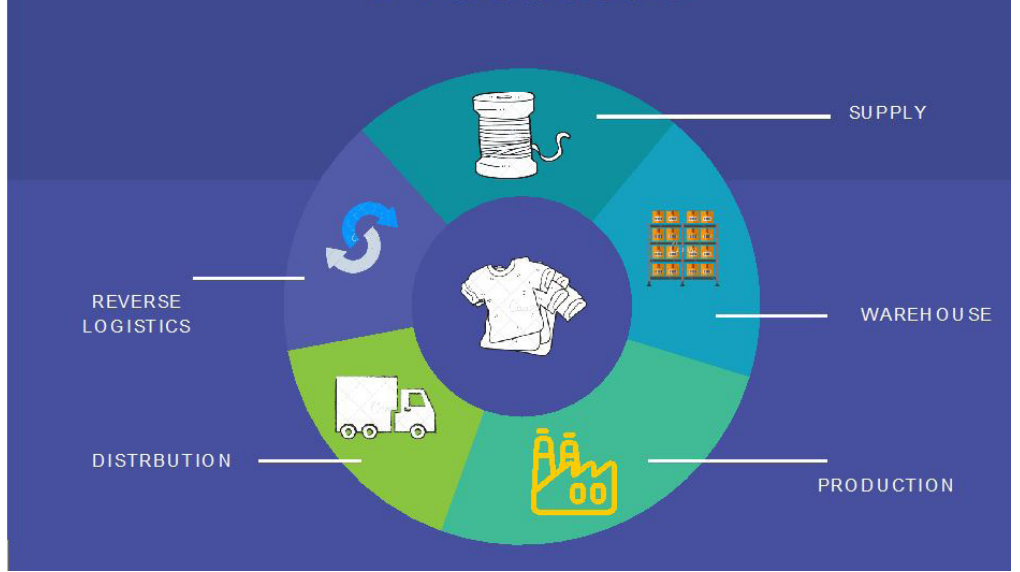

Figure 1. Processes of a Fashion Supply Chain

and Bhattacharjee \& Cruz (2015) were considered as the starting point for modelling the reverse logistics process, appropriately adjusted and modified according to the textile field. However, it is worth mentioning that in practical cases, distribution is often the last activity under the control of a fashion supply chain: after that process, the responsibility lies with the last actors of the supply chain. As far as the warehouse process is concerned, its detailed description and modelling were provided in a previous publication (i.e. Bottani et al., 2019), which the reader is referred to for further details; hence, it is not detailed in the present manuscript.

For each process, a detailed set of analytic formulae, together with appropriate conversion factors, are proposed for computing the total cost [€/years] and total emissions $\left[\mathrm{kgCO}_{2} /\right.$ year] of the supply chain; these outcomes were chosen as appropriate measurement units for the quantitative evaluation of the economic and environmental sustainability.

The whole set of formulae was embodied in a Microsoft Excel ${ }^{\mathrm{TM}}$ file to automate the computation. The Microsoft Excel $^{\mathrm{TM}}$ file consists of six spreadsheets; five of them represent the fashion supply chain processes and evaluate both the economic and environmental aspects of the process sustainability. The last spreadsheet aggregates the results of the processes for a better understanding of the whole supply chain sustainability.

Formulae and nomenclature are provided for both dimensions in the subsections that follow. Note that the units of measurement mentioned can be properly converted according to the available data in the application of the model. Interested readers are also welcomed to ask the authors for the full model.

\subsection{Modelling of supply chain processes}

\subsubsection{Supply}

The supply stage of a fashion supply chain basically corresponds to the purchase of raw materials (RMs) from different suppliers, allowing the realization of finished products which result from the production step (i.e. the second process modelled in this work). The two main activities contributing to the generation of costs and emissions are the following:

- Purchase of RMs from different suppliers;

- Transport of RMs from these suppliers to the main warehouses.

As far as the first activity, it is necessary to identify the various RMs purchased and their respective suppliers, quantities involved (e.g. kilograms or other appropriate units of measure) and the unit purchase cost. As regards the transport, in addition to the carried quantities, the distance covered by the transport mean (e.g. in kilometres) shall be known, or at least suppliers' geographical position in order to compute the distance; these values will 
determine the number of deliveries from each supplier. Furthermore, appropriate coefficients indicating the unitary cost and the emissions are required, which vary according to the transport means, i.e. by road, rail, air or sea.

Note that the RMs purchase was considered only for the economic assessment, as it does not generate any emissions. Table 1 below shows the nomenclature involved for both the economic and the environmental dimensions considered.

Table 1. Nomenclature for the economic and environmental modelling of the supply process.

\begin{tabular}{|c|c|c|c|c|c|}
\hline SYMBOL & DESCRIPTION & $\begin{array}{l}\text { UNIT OF } \\
\text { MEASUREMENT }\end{array}$ & SYMBOL & DESCRIPTION & $\begin{array}{l}\text { UNIT OF } \\
\text { MEASUREMENT }\end{array}$ \\
\hline$m$ & Raw material $(1, . ., \mathrm{M})$ & - & $c_{t}$ & $\begin{array}{l}\text { Transport unitary cost (for the } \\
t \text { transport means) }\end{array}$ & $€ / \mathrm{km}$ or $€ /$ journey \\
\hline$f$ & Supplier $(1, \ldots, F)$ & - & $C_{P}$ & Total purchase cost & $€ /$ year \\
\hline$t$ & Transport means $(1, . ., T)$ & - & $C_{T}$ & Total transport cost & $€ /$ year \\
\hline$q_{m f}$ & $\begin{array}{l}\text { Quantity of RM } m \text { purchased from } \\
\text { supplier } f\end{array}$ & $\mathrm{~kg}$ or ton & Cs & $\begin{array}{l}\text { Total costs of the supply } \\
\text { process }\end{array}$ & $€ /$ year \\
\hline$c_{m f}$ & $\begin{array}{l}\text { Unitary cost of RM } m \text { purchased from } \\
\text { supplier } f\end{array}$ & $€ / \mathrm{kg}$ or $€ /$ ton & $e_{t}$ & $\begin{array}{l}\text { Unitary emissions (for the } \\
t \text { transport means) }\end{array}$ & $\begin{array}{c}\mathrm{kgCO}_{2} / \mathrm{km} \text { or } \\
\mathrm{kgCO}_{2} /\left(\text { ton }^{*} \mathrm{~km}\right)\end{array}$ \\
\hline$d_{f}$ & $\begin{array}{l}\text { Distance from supplier } f \text { to the } \\
\text { destination }\end{array}$ & $\mathrm{km}$ & $E_{T}$ & $\begin{array}{l}\text { Total emissions due to the } \\
\text { transport }\end{array}$ & $\mathrm{kgCO}_{2} /$ year \\
\hline$Q_{t}$ & Means of transport's $t$ capacity & $\mathrm{kg}$, ton or $\mathrm{u}$ & $E_{S}$ & $\begin{array}{l}\text { Total emissions of the supply } \\
\text { process }\end{array}$ & $\mathrm{kgCO}_{2} /$ year \\
\hline $\mathrm{N}_{\mathrm{f}}$ & Number of journeys from $f$ supplier & - & & & \\
\hline
\end{tabular}

The set of formulae considered in the model for computing the desired values, instead, is below listed (equations from 1 to 7 ).

- Cost for the purchasing of RMs:

$$
C_{P}=\sum_{m=1}^{M} \sum_{f=1}^{F} c_{m f} q_{m f}[€ / \text { year }]
$$

- number of deliveries from $f$ supplier:

$$
N_{f}=\left[\frac{q_{m f}}{Q_{t}}\right]
$$

- cost for the transport of RM:

$$
C_{T}=\sum_{t=1}^{T} \sum_{f=1}^{F} c_{t} N_{f} d_{f} \quad[€ / \text { year }]
$$

when $c_{t}$ is expressed in $€ / \mathrm{km}$

$$
C_{T}=\sum_{t=1}^{T} \sum_{f=1}^{F} c_{t} N_{f}[€ / \text { year }]
$$

when $c_{t}$ is expressed in $€ /$ journey

- total costs of the supply process:

$$
C_{S}=C_{P}+C_{T} \quad[€ / \text { year }]
$$

- emissions due to the RMs transport, corresponding to the total emissions generated at this stage:

$$
E_{T} \equiv E_{S}=\sum_{t=1}^{T} \sum_{f=1}^{F} e_{t} N_{f} d_{f}[\mathrm{kgCO} 2 / \mathrm{year}]
$$

when $e_{t}$ is expressed in $\mathrm{kgCO}_{2} / \mathrm{km}$

$$
E_{T} \equiv E_{S}=\sum_{t=1}^{T} \sum_{f=1}^{F} e_{t} d_{f} Q_{t} N_{f}[\mathrm{kgCO} 2 / \text { year }]
$$

when $e_{t}$ is expressed in $\mathrm{kgCO}_{2} /\left(\mathrm{ton}^{*} \mathrm{~km}\right)$ 


\subsubsection{Production}

With regard to the second process presented, namely production, it is first necessary to distinguish between in-house production or outsourced production. Indeed, on the basis their availability and capacity, companies may decide whether to carry out production in-house, or to outsource it especially abroad both in plants owned by the company itself or by third parties (called façon in the fashion context).

To make the analysis complete and exhaustive, we considered both scenarios in the following subsections.

\subsubsection{In-house production}

In this first case, for both the economic and the environmental evaluation, unitary costs and emissions for the different production processes allowing for the manufacturing of finished products were considered; according to that, the two values simply depend on the volumes of finished items produced in the unit of time in question.

Furthermore, the energy consumption due to lighting, heating and cooling of facilities in which production is carried out is included in the environmental assessment, as its cost is already embodied in the unitary cost of production; volumes dedicated to each process were taken into account in this computation. Table 2 lists the parameters involved, assuming an automated production and consequently not including workers contribute.

Formulae developed (from 8 to 11):

- cost for production processes, corresponding to the total costs for this stage:

$$
C_{P R I N}=\sum_{p=l l=1}^{P} \sum_{p}^{L} n_{p} c_{l p}[€ / \text { year }]
$$

Table 2. Nomenclature for the economic and environmental modelling of the in-house production.

\begin{tabular}{|c|c|c|c|c|c|}
\hline SYMBOL & DESCRIPTION & $\begin{array}{l}\text { UNIT OF } \\
\text { MEASUREMENT }\end{array}$ & SYMBOL & DESCRIPTION & $\begin{array}{c}\text { UNIT OF } \\
\text { MEASUREMENT }\end{array}$ \\
\hline$p$ & Product or product category $(1, \ldots, \mathrm{P})$ & - & $V_{1}$ & Volumes dedicated to $I$ process & $\mathrm{m}^{3}$ \\
\hline l & Production process $(1, \ldots, \mathrm{L})$ & - & $\vartheta$ & $\begin{array}{l}\text { Unitary energy consumption } \\
\text { coefficient }\end{array}$ & $\mathrm{kWh} / \mathrm{m}^{3} /$ year \\
\hline$n_{p}$ & $\begin{array}{l}\text { Number of units produced per product } \\
\text { category }\end{array}$ & $\mathrm{U}$ & $E_{P R I N}$ & $\begin{array}{l}\text { Total emissions for in house } \\
\text { production }\end{array}$ & $\mathrm{kgCO}_{2} /$ year \\
\hline$c_{l p}$ & Unitary cost of process $I$ for processing $p$ & $€ / u$ & $E_{E N}$ & Emissions due to energy & $\mathrm{kgCO}_{2} /$ year \\
\hline$C_{P R I N}$ & Total cost for in house production & $€ /$ year & $E_{P R}$ & $\begin{array}{l}\text { Emissions from the production } \\
\text { processes }\end{array}$ & $\mathrm{kgCO}_{2} /$ year \\
\hline$e_{l p}$ & $\begin{array}{l}\text { Unit emission of process } I \text { for } \\
\text { processing } p\end{array}$ & $\mathrm{kgCO}_{2} / \mathrm{u}$ & E & Conversion factor $\mathrm{kWh} \rightarrow \mathrm{kgCO} 2$ & $\mathrm{kgCO}_{2} / \mathrm{kWh}$ \\
\hline
\end{tabular}

- emissions from production processes:

$$
E_{P R}=\sum_{p=l l=1}^{P} \sum_{l=1}^{L} n_{p} e_{l p}\left[\mathrm{kgCO}_{2} / \text { year }\right]
$$

- emissions from energy consumption (lighting, heating and cooling of facilities):

$$
E_{E N}=\sum_{l=1}^{L} V_{l} \vartheta E\left[\mathrm{kgCO}_{2} / \text { year }\right]
$$

- total emissions for in-house production process:

$$
E_{P R I N}=E_{P R}+E_{E N}\left[\mathrm{kgCO}_{2} / \text { year }\right]
$$




\subsubsection{Outsourced production}

The second case referred in this model concerns the outsourced production. Raw materials, located in the warehouses owned by a generic company, are shipped by this last to the production plants where the real production will take places (Forward Flow - FF). Once manufacturing is over and finished products are completed, they back to the initial origin (Backward Flow - BF).

According to that, in our assessment only these two flows were taken into account and consequently, only logistics operations i.e. basically the transport, were considered. The total contributions are obtained as the sum of the FF and the BF. Preliminary and essential information concerns the geographical location of the production plants, which can be either abroad or in the same country, the transport means and the volumes involved, both of raw materials and finished products. Moreover, in the fashion industry, it can sometimes happen that companies directly buy finished products from third parties without being involved in the RMs flow; typically, these third parties are the same where production is carried out. This option has also been included in the evaluation, by considering the number of units sold and their relative unitary cost.

Parameters are below summarized, in Table 3, with their relative nomenclature.

Table 3. Nomenclature for the economic and environmental modelling of the outsourced production.

\begin{tabular}{|c|c|c|c|c|c|}
\hline SYMBOL & DESCRIPTION & $\begin{array}{c}\text { UNIT OF } \\
\text { MEASUREMENT }\end{array}$ & SYMBOL & DESCRIPTION & $\begin{array}{c}\text { UNIT OF } \\
\text { MEASUREMENT }\end{array}$ \\
\hline$m$ & Raw material $(1, . ., \mathrm{M})$ & - & $C_{P R P}$ & $\begin{array}{l}\text { Total cost for direct } \\
\text { purchase of } P \text { products }\end{array}$ & $€ /$ year \\
\hline$p$ & $\begin{array}{l}\text { Product or product category } \\
(1, \ldots, P)\end{array}$ & - & $C_{P R F F}$ & Total cost for FF (transport) & $€ /$ year \\
\hline$t$ & Transport means $(1, \ldots, T)$ & - & $C_{P R B F}$ & $\begin{array}{l}\text { Total cost for BF } \\
\text { (transport) }\end{array}$ & $€ /$ year \\
\hline$s$ & Production plant $(1, \ldots, S)$ & - & $C_{\text {PROUT }}$ & $\begin{array}{l}\text { Total cost for outsourced } \\
\text { production }\end{array}$ & $€ /$ year \\
\hline$d_{s}$ & $\begin{array}{l}\text { Distance from the } s \\
\text { production plant (to the } \\
\text { main warehouse) }\end{array}$ & $\mathrm{km}$ & $E_{\text {PRFF }}$ & Total emissions for FF & $\mathrm{kgCO}_{2} /$ year \\
\hline$q_{m s}$ & $\begin{array}{l}\text { Quantity of RM } m \text { sent to the } \\
s \text { production plant }\end{array}$ & $\mathrm{kg}$ & $E_{P R B F}$ & Total emissions for BF & $\mathrm{kgCO}_{2} /$ year \\
\hline$q_{p s}$ & $\begin{array}{l}\text { Quantity of } \mathrm{P} \text { items returning } \\
\text { from the } s \text { production plant }\end{array}$ & $\mathrm{u}$ & $E_{\text {PROUT }}$ & $\begin{array}{l}\text { Total emissions for } \\
\text { outsourced production }\end{array}$ & $\mathrm{kgCO}_{2} /$ year \\
\hline$Q_{t}$ & $\begin{array}{l}\text { Capacity of the transport } \\
\text { means }\end{array}$ & $\mathrm{kg}$, Ton or u & $N_{\mathrm{FF}}$ & $\begin{array}{l}\text { Number of FF journeys to } \\
\text { production plant } s\end{array}$ & - \\
\hline$c_{t}$ & $\begin{array}{l}\text { Transport unitary cost (for } \\
\text { the } t \text { transport means) }\end{array}$ & $€ / \mathrm{km}$ or $€ /$ journey & $N_{\mathrm{BF}}$ & $\begin{array}{l}\text { Number of BF journeys } \\
\text { from production plant } s\end{array}$ & - \\
\hline$n_{p s}$ & $\begin{array}{l}\text { Number of } p \text { product } \\
\text { purchased from production } \\
\text { plant } s\end{array}$ & $\mathrm{u}$ & $c_{p r}$ & $\begin{array}{l}\text { Unitary cost of } p \text { product } \\
\text { purchased }\end{array}$ & $€ / u$ \\
\hline$e_{t}$ & $\begin{array}{l}\text { Unitary emissions (for the } t \\
\text { transport means) }\end{array}$ & $\begin{array}{c}\mathrm{kgCO}_{2} / \mathrm{km} \text { or } \\
\mathrm{kgCO}_{2} /\left(\text { ton }^{*} \mathrm{~km}\right)\end{array}$ & & & \\
\hline
\end{tabular}

We have now all the elements necessary to provide the exact formulae for computing partial results and overall values for the costs and the emissions resulting from the outsourced production (equations from 12 to 24):

- ost for the direct purchase of finished products:

$$
C_{P R P}=\sum_{p=1 s=1}^{P} \sum_{p s}^{S} n_{p r} c_{p r}[€ / \text { year }]
$$

- number of deliveries from the main warehouse to the s production plant:

$$
N_{F F}=\left[\frac{q_{m s}}{Q_{t}}\right]
$$

- cost for the FF, namely the RMs transport:

$$
C_{P R F F}=\sum_{s=1 t=1}^{S} \sum_{t}^{T} c_{t} N_{F F} d_{s}[€ / \text { year }]
$$

when $c_{t}$ is expressed in $€ / \mathrm{km}$ 


$$
C_{P R F F}=\sum_{s=1 t=l}^{S} \sum_{t=1}^{T} c_{t} N_{F F}[€ / \text { year }]
$$

when $c_{t}$ is expressed in $€ /$ journey

- number of deliveries from the s production plant to the main warehouse:

$$
N_{B F}=\left[\frac{q_{p s}}{Q_{t}}\right]
$$

- cost for the BF, namely the finished products transport:

$$
C_{P R B F}=\sum_{s=1 t=1}^{S} \sum_{t}^{T} c_{t} N_{B F} d_{s} \quad[€ / \text { year }]
$$

when $c_{t}$ is expressed in $€ / \mathrm{km}$

$$
C_{P R B F}=\sum_{s=1 t=1}^{S} \sum_{t}^{T} c_{t} N_{B F} \quad[€ / \text { year }]
$$

when $c_{t}$ is expressed in $€ /$ journey

- total cost for the outsourced production:

$$
C_{\text {PROUT }}=C_{P R P}+C_{P R F F}+C_{P R B F} \quad[€ / \text { year }]
$$

- emissions for the FF:

$$
E_{P R F F}=\sum_{s=1 t=1}^{S} \sum_{t}^{T} e_{t} N_{F F} d_{s} \quad\left[\mathrm{kgCO}_{2} / \text { year }\right]
$$

when $e_{t}$ is expressed in $\mathrm{kgCO}_{2} / \mathrm{km}$

$$
E_{P R F F}=\sum_{m=1 s=1 t=1}^{M} \sum_{t}^{S} \sum_{t}^{T} e_{s} Q_{t} N_{F F} \quad\left[\mathrm{kgCO}_{2} / \text { year }\right]
$$

when $e_{t}$ is expressed in $\mathrm{kgCO}_{2} /\left(\right.$ ton $\left.^{*} \mathrm{~km}\right)$

- emissions for the BF:

$$
E_{P R B F}=\sum_{s=1 t=1}^{S} \sum_{t}^{T} e_{t} N_{B F} d_{s} \quad\left[\mathrm{kgCO}_{2} / \text { year }\right]
$$

when $e_{t}$ is expressed in $\mathrm{kgCO}_{2} / \mathrm{km}$

$$
E_{P R B F}=\sum_{p=1 s=1 t=1}^{P} \sum_{t}^{T} e_{t} d_{s} Q_{t} N_{B F}\left[\mathrm{kgCO}_{2} / \text { year }\right]
$$

when $e_{t}$ is expressed in $\mathrm{kgCO}_{2} /\left(\right.$ ton $\left.^{*} \mathrm{~km}\right)$

- total emissions for the outsourced production:

$$
E_{P R O U T}=E_{P R F F}+E_{P R B F}\left[\mathrm{kgCO}_{2} / \text { year }\right]
$$

\subsubsection{Distribution}

The role of this process is to make finished products available from the main warehouse owned by the company where they are stored once production is over to different actors which may be interested in receiving the items, e.g. carriers, wholesalers or retailers. In the model, these players are simply referred to as "destinations", and it is assumed that the flow starts from a single point. Surely, the first key information to be known is the geographic location of the different addressees, according to which the distance is determined; means of transport selected for each destination and the quantities which can be transported in each journey shall be determined, as well 
as the volumes requested by each destination. From these data, of the number of journeys needed can be easily computed. Unitary cost and emissions coefficients are crucial for the calculation.

In parametric terms, all this can be resumed as shown in Table 4.

Table 4. Nomenclature for the economic and environmental modelling of the distribution process.

\begin{tabular}{|c|c|c|c|c|c|}
\hline SYMBOL & DESCRIPTION & $\begin{array}{c}\text { UNIT OF } \\
\text { MEASUREMENT }\end{array}$ & SYMBOL & DESCRIPTION & UNIT OF MEASUREMENT \\
\hline$B$ & Destinations to be reached $(1, \ldots, \mathrm{B})$ & - & $c_{t}$ & $\begin{array}{l}\text { Unitary transport cost (for } \\
\text { the } t \text { transport means) }\end{array}$ & $€ / \mathrm{km}$ or $€ /$ journey \\
\hline$P$ & Product or product category $(1, \ldots, \mathrm{P})$ & - & $e_{t}$ & $\begin{array}{l}\text { Unitary emission (for the } t \\
\text { transport means) }\end{array}$ & $\mathrm{kgCO}_{2} / \mathrm{km} \mathrm{kgCO}_{2} /($ ton*km) \\
\hline$t$ & Transport means $(1, . ., \mathrm{T})$ & - & $N_{\mathrm{b}}$ & $\begin{array}{l}\text { Number of journeys } \\
\text { necessary for transporting the } \\
\text { quantities requested from } b \\
\text { destination }\end{array}$ & - \\
\hline$d_{b}$ & Distance of $b$ destination & $\mathrm{km}$ & $C_{D}$ & Total cost for distribution & $€ /$ year \\
\hline$q_{p b}$ & $\begin{array}{l}\text { Quantities of } p \text { products requested by } \\
b \text { destination }\end{array}$ & $\mathrm{u}$ & $E_{D}$ & $\begin{array}{l}\text { Total emissions for } \\
\text { distribution }\end{array}$ & $\mathrm{kgCO}_{2} /$ year \\
\hline$Q_{t}$ & Capacity of the $t$ transport means & $\mathrm{kg}$, Ton or u & & & \\
\hline
\end{tabular}

The abovementioned number of journeys required for transferring the quantities requested by the $b$ destination according to the quantities which can be transported by the transport means chosen, is determined by considering the next whole of the following ratio:

$$
N_{b}=\left[\frac{q_{p b}}{Q_{t}}\right]
$$

Overall, the values requested for evaluating the economic and environmental dimensions generated from this activity are determined as follows (equations from 26 to 29):

- Total costs for the distribution step:

$$
C_{D}=\sum_{b=1 t=l}^{B} \sum_{t}^{T} c_{t} N_{b} d_{f} \quad[€ / \text { year }]
$$

when $c_{t}$ is expressed in $€ / \mathrm{km}$

$$
C_{D}=\sum_{b=1 t=1}^{B} \sum_{t}^{T} c_{t} N_{b}[€ / \text { year }]
$$

when $c_{t}$ is expressed in $€ /$ journey

- Total emissions for the distribution step:

$$
E_{D}=\sum_{b=1 t=1}^{B} \sum_{t}^{T} e_{t} N_{b} d_{s} \quad\left[\mathrm{kgCO}_{2} / \text { year }\right]
$$

when $e_{t}$ is expressed in $\mathrm{kgCO}_{2} / \mathrm{km}$

$$
E_{D}=\sum_{p=l}^{P} \sum_{b=1}^{B} \sum_{t=1}^{T} e_{t} d_{b} Q_{t} N_{b} \quad\left[\mathrm{kgCO}_{2} / \text { year }\right]
$$

when $e_{t}$ is expressed in $\mathrm{kgCO}_{2} /\left(\right.$ ton $\left.^{*} \mathrm{~km}\right)$

\subsubsection{Reverse logistics}

The Reverse Logistics Executive Council provides the following definition for reverse logistics: the process of planning, implementing, and controlling the efficient, cost effective flow of raw materials, in-process inventory, finished goods, and related information from the point of consumption to the point of origin for the purpose of recapturing value or of proper disposal (Tibben-Lembke \& Rogers, 1998). 
In line with this, it has been assumed that the reverse supply chain includes a main collection centre where returned items (e.g. unsold products directly in the stores, faulty products coming from wholesalers or returns from customers) converge from the different points of consumption. From that facility, goods are then destinated to a centre where they will be subjected to check in order to assess whether they can be recovered or disposed, corresponding to the point of origin for valorisation or disposal of the abovementioned definition. According to that, the activities generating cost and emissions considered are the following:

- Transport from the collection centre to the point of control and subsequent actions;

- Products control for assessing the status of the goods;

- Recovery;

- Disposal.

Note that it was hypothesized that checks on returned products are carried out manually, and therefore do not generating emissions.

As far as the transport, it was not conceived in terms of the volumes of products transferred, but rather on the number of journeys from the collection centre to the point of control in order to simplify the model, as data related to the correct amount of collected items are not always available. On the contrary, for the remaining steps, the exact number of products checked and then recovered or disposed was taken into account, considering then the unitary cost and emissions for each of the three operations.

The required parameters for modelling this process are listed in Table 5, assuming hypothetically that there are two possible recovery processes; typically, in the fashion field, these processes can be for instance relabelling, rewrapping or washing, but more processes can be involved according to the product in question. Another assumption made in order to be more thorough is that unitary costs and emissions of each process vary according to the category of product treated; anyway, it is also possible to impose that each process has the same cost and emission for the whole set of products.

Table 5. Nomenclature for the economic and environmental modelling of the reverse logistics process.

\begin{tabular}{|c|c|c|c|c|c|}
\hline SYMBOL & DESCRIPTION & $\begin{array}{c}\text { UNIT OF } \\
\text { MEASUREMENT }\end{array}$ & SYMBOL & DESCRIPTION & $\begin{array}{c}\text { UNIT OF } \\
\text { MEASUREMENT }\end{array}$ \\
\hline$r$ & Collection centre $(1, . ., R)$ & - & $\mathrm{e}_{R E C / p}$ & $\begin{array}{l}\text { Unitary emission for the REC1 } \\
\text { recovery process for the } p \text { product }\end{array}$ & $\mathrm{kgCO}_{2} / \mathrm{kg}$ \\
\hline$t$ & Transport means $(1, \ldots, \mathrm{T})$ & - & $\mathrm{e}_{\text {RECZP }}$ & $\begin{array}{l}\text { Unitary emission for the REC2 } \\
\text { recovery process for the } p \text { product }\end{array}$ & $\mathrm{kgCO}_{2} / \mathrm{kg}$ \\
\hline$p$ & Product or product category $(1, \ldots, P)$ & - & $e_{D I S p}$ & $\begin{array}{l}\text { Unitary emission for the disposal } \\
\text { process for the } p \text { product }\end{array}$ & $\mathrm{kgCO}_{2} / \mathrm{kg}$ \\
\hline C & Process of control & - & $q_{c p}$ & Quantities of $p$ product checked & $\mathrm{kg}$ \\
\hline REC1 & Recovery process 1 & - & $q_{R E C / p}$ & $\begin{array}{l}\text { Quantities of } p \text { product subjected } \\
\text { to REC1 recovery process }\end{array}$ & $\mathrm{kg}$ \\
\hline REC2 & Recovery process 2 & - & $q_{\text {REC2P }}$ & $\begin{array}{l}\text { Quantities of } p \text { product subjected } \\
\text { to REC2 recovery process }\end{array}$ & $\mathrm{kg}$ \\
\hline DIS & Disposal process & - & $q_{D I S p}$ & $\begin{array}{l}\text { Quantities of } p \text { product subjected } \\
\text { to disposal process }\end{array}$ & $\mathrm{kg}$ \\
\hline$N_{r t}$ & $\begin{array}{l}\text { Number of journeys from } r \text { collection } \\
\text { centre by } t \text { transport means }\end{array}$ & - & $C_{c}$ & Cost for control & $€ /$ year \\
\hline$c v_{t}$ & $\begin{array}{l}\text { Cost for each journey by } t \text { transport } \\
\text { means }\end{array}$ & $€ /$ journey & $C_{R E C I}$ & Cost for recovery process 1 & $€ /$ year \\
\hline$e v_{t}$ & $\begin{array}{l}\text { Emissions for each journey by } t \\
\text { transport means }\end{array}$ & $\mathrm{kgCO}_{2} /$ journey & $C_{R E C 2}$ & Cost for recovery process 2 & $€ /$ year \\
\hline$C_{\mathrm{RLT}}$ & $\begin{array}{l}\text { Cost for the transport of the reverse } \\
\text { logistics process }\end{array}$ & $€ /$ year & $C_{D I S}$ & Cost for disposal & $€ /$ year \\
\hline$E_{R L T}$ & $\begin{array}{l}\text { Emissions for the transport of the } \\
\text { reverse logistics process }\end{array}$ & $\mathrm{kgCO}_{2} /$ year & $C_{R L}$ & Total cost for the reverse logistics & $€ /$ year \\
\hline$c_{c p}$ & $\begin{array}{l}\text { Unitary cost for the control process for } \\
\text { the } p \text { product }\end{array}$ & $€ / \mathrm{kg}$ & $E_{R E C I}$ & Emissions for recovery process 1 & $\mathrm{kgCO}_{2} /$ year \\
\hline$c_{R E C l p}$ & $\begin{array}{l}\text { Unitary cost for the REC } 1 \text { recovery } \\
\text { process for the } p \text { product }\end{array}$ & $€ / \mathrm{kg}$ & $E_{R E C 2}$ & Emissions for recovery process 2 & $\mathrm{kgCO}_{2} /$ year \\
\hline$c_{\text {RECZP }}$ & $\begin{array}{l}\text { Unitary cost for the REC } 2 \text { recovery } \\
\text { process for the } p \text { product }\end{array}$ & $€ / \mathrm{kg}$ & $E_{D I S}$ & Emissions for disposal & $\mathrm{kgCO}_{2} /$ year \\
\hline$c_{D I S p}$ & $\begin{array}{l}\text { Unitary cost for the disposal process } \\
\text { for the } p \text { product }\end{array}$ & $€ / \mathrm{kg}$ & $E_{R L}$ & $\begin{array}{l}\text { Total emissions for the reverse } \\
\text { logistics }\end{array}$ & $\mathrm{kgCO}_{2} /$ year \\
\hline
\end{tabular}


Total costs and emissions incurring for the aforementioned activities are obtained as follows (equations from 30 to 40):

- cost for the transport of the reverse logistics:

$$
C_{R L T}=\sum_{t=1}^{T} \sum_{r=1}^{R} N_{r t} c v_{t} \quad[€ / \text { year }]
$$

- emissions for transport of the reverse logistics:

$$
E_{R L T}=\sum_{t=1 r=1}^{T} \sum_{r=1}^{R} N_{r t} e v_{t}\left[\mathrm{kgCO}_{2} / \text { year }\right]
$$

- cost for the control of products:

$$
C_{C}=\sum_{p=1}^{P} c_{C p} q_{C p}[€ / \text { year }]
$$

- cost for the recovery process 1 :

$$
C_{R E C l}=\sum_{p=1}^{P} c_{R E C l p} q_{R E C l p}[€ / \text { year }]
$$

- cost for the recovery process 2 :

$$
C_{R E C 2}=\sum_{p=1}^{P} c_{R E C 2 p} q_{R E C 2 p}[€ / \text { year }]
$$

- cost for the disposal:

$$
C_{D I S}=\sum_{p=1}^{P} c_{D I S p} q_{D I S p}[€ / \text { year }]
$$

- total cost for the reverse logistics:

$$
C_{R L}=C_{R L T}+C_{C}+C_{R E C 1}+C_{R E C 2}+C_{D I S} \quad[€ / \text { year }]
$$

- emissions for the recovery process 1 :

$$
E_{R E C l}=\sum_{p=1}^{P} e_{R E C l p} q_{R E C l p}\left[\mathrm{kgCO}_{2} / \text { year }\right]
$$

- emissions for the recovery process 2 :

$$
E_{R E C 2}=\sum_{p=1}^{P} e_{R E C 2 p} q_{R E C 2 p}\left[\mathrm{kgCO}_{2} / \text { year }\right]
$$

- emissions for the disposal:

$$
E_{D I S}=\sum_{p=1}^{P} e_{D I S p} q_{D I S p}\left[\mathrm{kgCO}_{2} / \text { year }\right]
$$


- total emissions for the reverse logistics:

$$
E_{R L}=E_{R L T}+E_{R E C 1}+E_{R E C 2}+E_{D I S}\left[\mathrm{kgCO}_{2} / \text { year }\right]
$$

\subsection{Input data}

The full list of input data required for the application of the model described above is provided in Appendix A. The source of data is also proposed, to clarify which data are to be collected in a real case study and which data can be derived from appropriate sources. For completeness, the list of data covers also the warehousing process.

\section{The case study}

\subsection{Overview of the company and supply chain}

To test its effectiveness, the model was applied to the case of an ltalian company operating in the fashion field and producing medium-high level ladieswear. Real data referring to the supply, warehouse, production, and distribution processed in 2017 were directly collected through interviews with the company's management; as far as the missed data, namely the coefficients for determining the transport's emissions, they were found on the Internet (sources are below provided).

The company in question, generically called Company A, is located in northern ltaly and acts as the focal company of its supply chain; production of ladieswear is planned based on orders received from the various point of sales, after they have sight of the new seasonal collection, reflecting a demand-driven supply chain (lannone et al., 2015). There are two main types of finished products i.e. knitting and jersey, for which different chains are involved due to the substantial difference of raw materials and processes between the two. Only in the distribution phase this difference disappears since all products are shipped together. Around 2,000,000 items per category are produced in one year.

The product flow starts with the procurement of raw materials; these latter can come from Turkey, India, Poland, Egypt and ltaly. Once goods are received at the Italian warehouse, they are shipped to the production plants. A key characteristic of Company A is that production is carried out by third parties situated abroad (typically in the Far East), in line with the common trend due to globalization of shifting production sites to emerging markets and developing countries (Warasthe \& Brandenburg, 2018); moreover, some finished products are directly bought from these manufacturers. Once the items have been manufactured, they are shipped back to the Italian warehouse, and finally they are delivered to the shippers' logistics platforms; at this point the company's control ends. In line with this, reverse logistics activities are not managed by Company A: once finished products reach the different points of sales, these last are responsible for their sale or for managing return flows.

\subsection{Process sustainability evaluation}

On the basis of the supply chain description, for the company taken as case study, the evaluation of the economic and environmental sustainability has been made on the following key processes: 1) supply, 2) warehouse, 3) production and 4) distribution. Reverse logistics has instead been excluded from the evaluation because, as mentioned, the flow of returned items falls outside the company's control; accordingly, the relating data were not available.

For the sake of brevity, the steps required for the evaluation of the economic and environmental sustainability are detailed (in terms of input data and application of the model formulae) for some processes only, namely:

- The supply process, which is detailed in terms of all data and formulae used for the evaluation of the economic sustainability; and

- the production process, which is detailed in terms of all data and formulae used for the evaluation of the environmental sustainability.

(we recall that the warehousing process was fully detailed in a previous publication by Bottani et al., 2019). The two processes listed above were chosen for presenting the model application because, on the basis of the 
outcomes, production and supply turned out to be the most impactful processes in environmental and economic terms, respectively. Nonetheless, numerical results will be provided for all supply chain processes analyzed, by distinguishing, where applicable, among the knitting and jersey product categories.

\subsubsection{Supply}

The main warehouse where raw materials should arrive is sited in a city located in the well-known food valley in Emilia Romagna region (North of ltaly). Two different materials are purchased, namely yarn for knitting clothes, and tissue for the jersey category; according to that, in this specific case $m=[1 ; 2]$.

Input data for computing the total purchasing costs on the bases of equation 1 are resumed in the Tables 6 and 7, which are divided on purpose for $m=1$ (yarn) and $m=2$ (tissue); the source of such information is directly the purchasing department of Company A. Note that tissue is sold by meter, accordingly appropriate equivalences and rounding were applied.

Table 6. Input data for determining the purchasing cost of $m=1$.

\begin{tabular}{ccccc}
\hline SUPPLIER & $\mathrm{F}$ & $\mathrm{q}_{1 \mathrm{f}}$ & $\mathrm{c}_{1 \mathrm{f}}$ & Partial $_{\mathrm{p}}[€ /$ year] \\
\hline Italy (BS) & 1 & 44,000 & 4.3 & 189,200 \\
Italy (FI) & 2 & 49,000 & 3.6 & 178,560 \\
Italy (CO) & 3 & 52,000 & 3.4 & 176,800 \\
Italy (PO) & 4 & 37,600 & 4.2 & 157,920 \\
Italy (MI) & 5 & 22,400 & 7.1 & 159,040 \\
Poland & 6 & 68,000 & 2.1 & 142,800 \\
Turkey & 7 & 76,000 & 1.89 & 143,640 \\
India & 8 & 50,400 & 10.5 & 529,200
\end{tabular}

Table 7. Input data for determining the purchasing cost of $m=2$.

\begin{tabular}{ccccc}
\hline SUPPLIER & $\mathrm{f}$ & $\mathrm{q}_{2 \mathrm{f}}$ & $\mathrm{c}_{2 \mathrm{f}}$ & Partial $\mathrm{C}_{\mathrm{p}}[€ /$ year] \\
\hline Italy (CO) & 3 & 22,400 & 7.45 & 166,880 \\
Italy (PO) & 4 & 24,000 & 8.33 & 199,920 \\
Italy (VA) & 9 & 20,000 & 5.65 & 113,000 \\
Italy (T0) & 10 & 25,600 & 6.25 & 160,000 \\
Turkey & 7 & 48,000 & 3.3 & 158,400 \\
India & 8 & 52,000 & 2.4 & 124,800 \\
Egypt & 11 & 48,000 & 2.7 & 129,600 \\
Total Cost for tissue purchase [€/year]: 1,052,600 & & & &
\end{tabular}

Each supplier is generally named according to its location, in order to remain anonymous.

In view of the two partial results deriving from the purchasing of yarn and tissue, the total cost can be easily determined as the sum of the two values, equal to $2,729,760 € /$ year $\left(=C_{P}\right)$.

The second item to be considered in the economic analysis is the transport of these two materials. Two different modes are involved: road, which is used for transferring goods coming from ltaly and Poland, and sea, in case greater distances should be covered (Turkey, India and Egypt). Therefore, $t=[1 ; 2]$ where $t=1$ refers to road and the cost coefficient is expressed in $€ / \mathrm{km}, t=2$ to the sea for which the cost is evaluated in terms of the number of journeys [€/journey].

The cost coefficient for the transport by road (i.e. $c_{1}$ ) is the cost ascribed by Company A; the cost for the transport by sea as well (i.e. $c_{2}$ ) was provided by the purchasing department. With regard to this latter value, it is clarified that Company A assumes to transport $3 \mathrm{TEU} /$ journey (TEU stands for Twenty feet Equivalent Unit), costing $872 €$ each; according to that, the cost for each journey is $2,616 €$. It is assumed a value equal to 27,000 for the capacity of the vehicle by road $\left(Q_{f}\right)$, while each TEU can contain 10,560 kg; accordingly, $31,680 \mathrm{~kg}\left(\mathrm{Q}_{2}\right)$ for each journey.

Input data are below provided in Table 8 for yarn and Table 9 for tissue.

By applying eq. 3 and 4 respectively for $t=1$ and $t=2$, it is immediately possible to determine the overall cost for the RMs transport ( $=\mathrm{C}_{\mathrm{T}}$ ), accounting to specifically $36,876.80 € /$ year. Finally, thanks this time to formula (5), the total costs incurring at the supply stage amounts to $2,766,636.80 € /$ year $\left(=\mathrm{C}_{\mathrm{s}}\right)$. 
Table 8. Input data for determining the transport cost of $m=1$.

\begin{tabular}{ccccccc}
\hline SUPPLIER & $\mathrm{f}$ & $\mathrm{d}_{\mathrm{f}}$ & $\mathrm{N}_{\mathrm{f}}$ & $\mathrm{t}$ & $\mathrm{c}_{\mathrm{t}}$ & Partial $\mathrm{C}_{\mathrm{T}}[€ /$ year $]$ \\
\hline Italy (BS) & 1 & 202 & 2 & 1 & $1.22 € / \mathrm{km}$ & 492.88 \\
Italy (FI) & 2 & 149 & 2 & 1 & $1.22 € / \mathrm{km}$ & 363.56 \\
Italy (CO) & 3 & 205 & 2 & 1 & $1.22 € / \mathrm{km}$ & 500.20 \\
Italy (PO) & 4 & 166 & 2 & 1 & $1.22 € / \mathrm{km}$ & 405.04 \\
Italy (MI) & 5 & 196 & 1 & 1 & $1.22 € / \mathrm{km}$ & 239.12 \\
Poland & 6 & 1,391 & 3 & 1 & $1.22 € / \mathrm{km}$ & $5,091.06$ \\
Turkey & 7 & 1,915 & 3 & 2 & $2,616 € /$ journey & 7,848 \\
India & 8 & 6,500 & 2 & 2 & $2,616 € /$ journey & 5,232 \\
\hline
\end{tabular}

Table 9. Input data for determining the transport cost of $m=2$.

\begin{tabular}{ccccccc}
\hline SUPPLIER & $\mathrm{f}$ & $\mathrm{d}_{\mathrm{f}}$ & $\mathrm{N}_{\mathrm{f}}$ & $\mathrm{t}$ & $\mathrm{c}_{\mathrm{t}}$ & Partial $_{\mathrm{T}}[€ /$ year] \\
\hline Italy (CO) & 3 & 196 & 1 & 1 & $1.22 € / \mathrm{km}$ & 239.12 \\
Italy (PO) & 4 & 166 & 1 & 1 & $1.22 € / \mathrm{km}$ & 202.52 \\
Italy (VA) & 9 & 185 & 1 & 1 & $1.22 € / \mathrm{km}$ & 225.70 \\
Italy (T0) & 10 & 280 & 1 & 1 & $1.22 € / \mathrm{km}$ & 341.60 \\
Turkey & 7 & 1,915 & 2 & 2 & $2,616 € /$ journey & 5,232 \\
India & 8 & 6,000 & 2 & 2 & $2,616 € /$ journey & 5,232 \\
Egypt & 11 & 2,300 & 2 & 2 & $2,616 € /$ journey & 5,232 \\
\hline
\end{tabular}

Table 10 below summarized results from the economic evaluation and also includes the environmental assessment, both divided according to knitting and jersey products.

As it is immediately possible to notice, costs for the supply are mostly due to the knitting product category. The reason is the very high unitary cost of the yarn used for these items, which is imported from India and shipped by sea.

Emissions as well are mainly generated by the knitting product category, since its RMs have a higher number of deliveries.

Table 10. Results from the economic and the environmental assessment of the supply function.

\begin{tabular}{cccccc}
\hline \multirow{2}{*}{ Type of Product } & \multicolumn{2}{c}{ Cost $[€ /$ year] } & & \multicolumn{2}{c}{ Emissions $\left[\mathrm{kgCO}_{2} /\right.$ /year] } \\
\cline { 2 - 3 } \cline { 5 - 6 } & Raw materials & Transport & & Raw materials & Transport \\
\hline Knitting & $1,677,160.00$ & $20,171.86$ & - & $17,118.33$ \\
Jersey & $1,052,600.00$ & $16,704.94$ & & & $13,610.57$ \\
Total & \multicolumn{2}{c}{$2,766,636.80$} & & & $30,728.90$ \\
\hline
\end{tabular}

\subsubsection{Production (outsourced)}

Since Company A outsources production, the evaluation has not been based on the processes themselves, but rather on forward flows (FF), i.e. the shipment of raw materials from the ltalian warehouse to the production plants abroad, and backward flows (BF), i.e. the product flow from the production plant to the ltalian warehouse. Volumes in the backward flow phase dealing with finished items are higher.

First of all, the part referring to the environmental assessment of FF will be discussed.

Again, road $(t=1)$ and ship $(t=2)$ are involved, and the same assumptions made for $Q_{1}$ and $Q_{2}$ are still valid. The same line of reasoning holds true for the costs, allocated on the bases of the quantities transported as far as road, and of the number of journeys for the transport by sea. Further input data are provided in the Tables 11 and 12, once again split among yarn (for knitting category) and tissue (for jersey category). In these tables, the different production plants are referred to with their home state.

The unit emission coefficient considered for the road transport, namely $e_{\text {, }}$, is equal to $0.91 \mathrm{kgCO}_{2} / \mathrm{km}$, and it was obtained by multiplying the emissions generated by 1 litre of diesel $\left(2.56 \mathrm{kgCO}_{2} /\right.$ litre (Quattroruote, 2017)) for the average diesel consumption of the articulated vehicle in question $(0.357$ litres $/ \mathrm{km}$, source the Italian Ministry for Transports, www.mit.gov.it). Instead, the same parameter for the sea transport, i.e. $e_{2}$, has been assumed to be $0.025 \mathrm{kgCO}_{2} /\left(\right.$ ton $^{*} \mathrm{~km}$ ) (source http://timeforchange.org/co2-emissions-shipping-goods); unlike 
Table 11. Input data for determining the transport emissions of $m=1$ (FF).

\begin{tabular}{cccccc}
\hline PRODUCTION PLANT & $\mathrm{s}$ & $\mathrm{T}$ & $\mathrm{d}_{\mathrm{s}}$ & $\mathrm{q}_{1 \mathrm{~s}}$ & $\mathrm{~N}_{\mathrm{FF}}$ \\
\hline Italy 1 & 1 & 1 & 308 & 40,000 & 2 \\
Italy 2 & 2 & 1 & 150 & 40,000 & 2 \\
Romania 1 & 3 & 1 & 1,728 & 80,000 & 3 \\
Romania 2 & 4 & 1 & 1,595 & 80,000 & 3 \\
Morocco & 5 & 2 & 2,100 & 80,000 & 3 \\
Tunisia & 6 & 2 & 1,200 & 80,000 & 3 \\
\hline
\end{tabular}

Table 12. Input data for determining the transport emissions of $m=2$ (FF).

\begin{tabular}{cccccc}
\hline PRODUCTION PLANT & $\mathrm{s}$ & $\mathrm{t}$ & $\mathrm{d}_{\mathrm{s}}$ & $\mathrm{q}_{\text {is }}$ & 3 \\
\hline ltaly & 7 & 1 & 204 & 60,000 & 80,000 \\
Croatia & 8 & 1 & 576 & 3 \\
Romania 1 & 3 & 1 & 1,728 & 100,000 \\
\hline
\end{tabular}

its cost, emissions are computed on the basis of distances rather than of the number of journeys. Moreover, in this case kilograms were properly converted into tons to be consistent with the remaining data.

In the light of what has been said, according to eq. 20 and 21, the overall emissions due to the forward flow of raw materials to the production plants are resumed in Table 13.

Table 13. Total emissions due to the Forward Flow of raw materials in the production stage.

\begin{tabular}{cc}
\hline & FF EMISSIONS $\left[\mathrm{kgCO}_{2} /\right.$ year $]$ \\
\hline YARN $(m=1)$ & $16,505.35$ \\
TISSUE $(m=2)$ & $8,419.32$ \\
TOTAL & $24,924.67$ \\
\hline
\end{tabular}

When dealing with the BF, instead, finished products are examines; consequently, the number of journeys is typically higher, in line with the increased volume of finished products compared with raw materials; indeed, a substantial percentage of finished items is directly purchased from production plants without managing the relating raw materials flow. In this case, China, Portugal and Turkey are included as origins of the product flows.

Volumes we discuss, as already stated, are around 2,000,000 units for each of the two categories. As far as the percentages of finishes products purchased, they amount to $50 \%$ from China for the knitting category $(p=1)$ and $70 \%$ for jersey products, namely $p=2$ (40\% from China, 15\% from Portugal and again 15\% from Turkey). The environmental assessment is once again made on the basis of the emissions due to the transport activities for moving goods; what is new is that air transport comes in as it is involved for the trade with China. Tables 14 and 15 provide the input data for the implement of eq. 22 and 23. Note that $t=3$ refers to the air transport, whose load capacity $Q_{3}$ necessary for computing the number of journeys amounts to 37,500 units of product. As far as the other load capacity, since in this case we deal with units instead of kilograms, account respectively for 15,840 in case of road transport $\left(Q_{1}\right)$ and 52,800 for sea transport $\left(Q_{2}\right)$. These values were obtained from interviews with managers of Company A, based on their experience.

The overall emissions due to the BF of finished products to the main warehouse sited in Reggio Emilia are summarized in Table 16. In the computation, the same emission coefficients as the FF were assumed; in addition, $0.676 \mathrm{kgCO} 2 /\left(\mathrm{ton}^{*} \mathrm{~km}\right.$ ) was set for the air transport (L'Inkiesta, 2017). Further assumptions made according to Company A's experience is that a journey by sea can carry approximately 21.16 tons of products $\left(Q_{2}\right.$ is therefore expressed in tons), while by air the amount of product carried is approximately 15.03 tons $\left(Q_{3}\right)$.

Table 14. Input data for determining the transport emissions of $p=1$ (BF).

\begin{tabular}{cccccc}
\hline PRODUCTION PLANT & $\mathrm{s}$ & $\mathrm{t}$ & $\mathrm{d}_{\mathrm{s}}$ & $\mathrm{q}_{\mathrm{s}}$ & $\mathrm{N}_{\mathrm{BF}}$ \\
\hline Italy 1 & 1 & 1 & 308 & 100,000 & 7 \\
Italy 2 & 2 & 1 & 150 & 100,000 & 7 \\
Romania 1 & 3 & 1 & 1,728 & 200,000 & 13 \\
Romania 2 & 4 & 1 & 1,595 & 200,000 & 13 \\
Morocco & 5 & 2 & 2,100 & 200,000 & 4 \\
Tunisia & 6 & 2 & 1,200 & 200,000 & 4 \\
China & 9 & 3 & 9,061 & $1,000,000$ & 27 \\
\hline
\end{tabular}


Table 15. Input data for determining the transport emissions of $p=2$ (BF).

\begin{tabular}{cccccc}
\hline PRODUCTION PLANT & $\mathrm{s}$ & $\mathrm{t}$ & $\mathrm{d}_{\mathrm{s}}$ & $\mathrm{q}_{1 \mathrm{~s}}$ & $\mathrm{~N}_{\mathrm{BF}}$ \\
\hline Italy & 7 & 1 & 204 & 150,000 & 10 \\
Croatia & 8 & 1 & 576 & 200,000 & 13 \\
Romania 1 & 3 & 1 & 1,728 & 250,000 & 16 \\
China & 9 & 3 & 9,061 & 800,000 & 22 \\
Portugal & 10 & 1 & 2,046 & 300,000 & 19 \\
Turkey & 11 & 2 & 1,915 & 300,000 & 6 \\
\hline
\end{tabular}

Table 16. Total emissions due to the Backward Flow of finished products in the production stage.

\begin{tabular}{cc}
\hline & BF EMISSIONS $\left[\mathrm{kgCO}_{2} /\right.$ year $]$ \\
\hline Knitting $(p=1)$ & $2,535,038.57$ \\
Jersey $(p=2)$ & $2,100,780.64$ \\
TOTAL & $4,660,743.88$ \\
\hline
\end{tabular}

Finally, both economic and environmental results from the outsourced production and accordingly corresponding to the transport activity, are resumed in Table 17. The reason for the gap between FF and BF is definitely the air transport, which is recognized for being the most expensive transport means, as well as polluting.

Table 17. Results from the economic and the environmental assessment of the production function.

\begin{tabular}{|c|c|c|c|c|}
\hline \multirow{2}{*}{ Type of Product } & \multicolumn{2}{|c|}{ Cost [€/year] } & \multicolumn{2}{|c|}{ Emissions $\left[\mathrm{kgCO}_{2} /\right.$ year] } \\
\hline & $\mathrm{FF}$ & $\mathrm{BF}$ & $\mathrm{FF}$ & $\mathrm{BF}$ \\
\hline Knitting & $28,975.70$ & $758,142.10$ & $16,505.35$ & $2,535,038.57$ \\
\hline Jersey & $11,287.44$ & $749,346.00$ & $8,419.32$ & $2,100,780.64$ \\
\hline Partial total & $40,263.14$ & $1,507,488.10$ & $24,924.67$ & $4,635,819.21$ \\
\hline Total & \multicolumn{2}{|c|}{$1,547,751.25$} & \multicolumn{2}{|c|}{$4,660,743.88$} \\
\hline
\end{tabular}

\subsubsection{Distribution}

The last activity analyzed is distribution. According to the case in question, we simply consider as distribution the shipment of the finished products to the shippers, which will then provide to real the distribution to the point of sales.

The outcomes obtained are shown in Table 18. Note that at this stage the distinction between knitwear and jersey disappears, since both product categories are distributed together.

Transport is only by road, and logistic platforms are all located in northern ltaly not far from the main warehouse of Company A on purpose.

Table 18. Results from distribution process.

\begin{tabular}{cc}
\hline Cost $[€ /$ year $]$ & Emissions $\left[\mathrm{kgCO}_{2} /\right.$ year $]$ \\
\hline $34,785.86$ & $25,946.83$ \\
\hline
\end{tabular}

\subsection{Aggregated results}

The aggregated results of the economic and environmental evaluation are presented in Table 19, including percentage share among the different supply chain processes. From these results it is evident that the supply process is the most expensive in economic terms, while the production process is the most impactful on the environment (as anticipated in section 4.1). More precisely, this last generates approximately $88 \%$ of the total emissions in the supply chain; this result clearly highlights that any effort for reducing the environmental impact of the supply chain under examination should start from a restructuring of the production process. To be more specific, recalling the outcomes in section 4.2.2, the knitting items are probably to be evaluated first. Similar considerations can be made for the supply process: in that case, if the company is interested in improving its economic sustainability, it would be reasonable to undertake actions directed towards cost reduction in this process. 


\begin{tabular}{ccccc}
\hline & Costs [€/year] & $\%$ & Emissions $\left[\mathrm{kgCO}_{2} /\right.$ year] & $\%$ \\
\hline Supply & $2,766,636.80$ & 59.1 & $30,728.90$ & 0.6 \\
Warehouse & $329,747.58$ & 7.1 & $577,074.60$ & 10.9 \\
Production & $1,547,751.25$ & 33.1 & $4,660,743.88$ & 88 \\
Distribution & $34,785.86$ & 0.7 & $25,946.83$ & 0.5 \\
TOTAL & $4,678,921.49$ & 100 & $5,294,494.21$ & 100 \\
\hline
\end{tabular}

\section{Discussion and conclusions}

This paper has presented a model for evaluating the economic and environmental sustainability of a fashion supply chain. The total cost was considered as the key performance measure for evaluating the economic aspect, while the amount of carbon dioxide emissions was used to evaluate the environmental dimension.

The model is analytic in nature and consists in a detailed set of formulae which were implemented in Microsoft Excel ${ }^{\mathrm{TM}}$ to automate the computational procedure; the approach takes into account all the typical processes of a fashion supply chain, from raw material procurement (supply stage) up to the shipment of the finished product to the stores (distribution stage).

For testing purpose, the model has subsequently been applied to an Italian company operating in the fashion industry. From the outcomes of the application, it emerged that most of the economic impact of the targeted company is generated at the supply stage; the second most relevant cost item is due to the production process. This latter also turns out to be responsible for almost all the environmental emissions of the supply chain. This result is even more relevant if considering that the environmental valuation only takes into account the logistics processes (i.e. the flows from the main Italian warehouse to the production plant and vice versa), because Company A outsources the production activity. Conversely, emissions due to the supply process are significantly lower than those due to the warehouse, especially generated from the heating and cooling systems. Specifically, it emerged that air transport, used to cover great distances, has a major impact on both costs and emissions.

These outcomes show that the model application has several practical implications. Indeed, evaluating the economic and environmental impact of the supply chain processes can be useful to the management to highlight those activities where the attention should be addressed and can support operational decisions aimed at decreasing the environmental impact of the company. In the specific case of the supply chain under examination, more sustainable means of transport could be suggested as an effective strategy to decrease the environmental impact of the production process. If we think that to prevent the climate change and global warming $\mathrm{CO}_{2}$ emissions should be minimized to 50\% of the 1990 level by 2050 (Palak et al., 2014), it is obvious that this last issue immediately deserves attention.

From a scientific point of view, this model grounds on the literature as for the identification of the key supply chain processes of the fashion supply chain. However, the scientific literature lacks quantitative models for evaluating economic and environmental sustainability of fashion supply chains. Hence, it is not immediate to compare the results obtained in our study with other available outcomes, for validation purpose. Nonetheless, results of our application confirm the findings of Shim et al. (2018) by showing that fashion supply chain can suffer from poor environmental performance, because of the long and complex chains. Also, our results appear in line with those of Boström \& Micheletti (2016), who highlighted the environmental impact of production of fashion items. Moreover, this study goes beyond some existing approaches to sustainability evaluation (e.g. Bottani et al., 2017), in that it allows a quantitative assessment of some sustainability perspectives and covers all the key supply chain processes.

Otherwise, the model developed in this paper can be taken as a starting point for other evaluations, both in the fashion field, in order to compare results as similar studies are lacking, and in other supply chains by adapting it to scenarios different from the fashion one (e.g. by changing processes or including other activities) depending on the particular context. Moreover, it can be implemented in companies of different size in order to identify any contingency factors.

There are, of course, some limitations in this study. First of all, the case study allowed for a quantitative assessment of various supply chain processes but entailed the impossibility of evaluating other processes. To be more precise, the case study could be more thorough if data about the true production process were available and included in the analysis. This was not the case, as production was outsourced in the targeted company. Similar considerations hold true for the reverse logistics process, which was not evaluated because it is not managed by the fashion company in question. For sure, testing the model on a company producing in-house is desirable and highly recommended, as well as on a company which also takes care of reverse logistics activity. From a 
methodological point of view, the social dimension of sustainability in not taken into account in the proposed approach; in future studies, its evaluation could be deepened to identify ways for quantitatively assessing it.

\section{References}

Aloise, P. G., \& Macke, J. (2017). Eco-innovations in developing countries: The case of Manaus Free Trade Zone (Brazil). Journal of Cleaner Production, 168, 30-38. http://dx.doi.org/10.1016/j.jclepro.2017.08.212.

Amindoust, A., \& Saghafinia, A. (2017). Textile supplier selection in sustainable supply chain using a modular fuzzy inference system model. Journal of the Textile Institute, 108(3), 1250-1258. http://dx.doi.org/10.1080/00405000.2016.1238130.

Azevedo, V. G., Portela Santos, A. A., \& Souza Campos, L. M. (2016). Corporate sustainability and asset pricing models: empirical evidence for the Brazilian stock market. Production, 26(3), 516-526. http://dx.doi.org/10.1590/0103-6513.201115.

Babu, S., \& Mohan, U. (2018). An integrated approach to evaluating sustainability in supply chains using evolutionary game theory. Computers \& Operations Research, 89, 269-283. http://dx.doi.org/10.1016/j.cor.2017.01.008.

Beh, L.-S., Ghobadian, A., He, Q., Gallear, D., \& O’Regan, N. (2016). Second-life retailing: A reverse supply chain perspective. Supply Chain Management, 21(2), 259-272. http://dx.doi.org/10.1108/SCM-07-2015-0296.

Bhattacharjee, S., \& Cruz, J. (2015). Economic sustainability of closed loop supply chains: A holistic model for decision and policy analysis. Decision Support Systems, 77, 67-86. http://dx.doi.org/10.1016/j.dss.2015.05.011.

Boström, M., \& Micheletti, M. (2016). Introducing the sustainability challenge of textiles and clothing. Journal of Consumer Policy, 39(4), 367-375. http://dx.doi.org/10.1007/s10603-016-9336-6.

Bottani, E., Rizzi, A., \& Vignali, G. (2015). Improving logistics efficiency of industrial districts: A framework and case study in the food sector. International Journal of Logistics: Research and Application, 18(5), 402-423. http://dx.doi.org/10.1080/13675567.2014.945401.

Bottani, E., Tebaldi, L., Lazzari, 1., \& Casella, G. (2019, August). A model for assessing economic and environmental sustainability dimensions of a fashion supply chain and a case study. In 9th IFAC Conference on Manufacturing Modeling, Management, and Control. Berlin, Germany. http://dx.doi.org/10.1016/j.ifacol.2019.11.147.

Bottani, E., Gentilotti, M. C., \& Rinaldi, M. (2017). A fuzzy logic-based tool for the assessment of corporate sustainability: A case study in the food machinery industry. Sustainability, 9(4), 583. http://dx.doi.org/10.3390/su9040583.

Capone, R., El Bilali, H., \& Bottalico, F. (2016). Assessing the sustainability of typical agro-food products: Insights from Apulia Region, Italy. New Medit, 1, 28-35.

Chen, Z., \& Andresen, S. (2014). A multiobjective optimization model of production-sourcing for sustainable supply chain with consideration of social, environmental, and economic factors. Mathematical Problems in Engineering, 2014, 1-11. http://dx.doi. org/10.1155/2014/616107.

Choi, T.-M., Cai, Y.-J., \& Shen, B. (2018). Sustainable fashion supply chain management: A system of systems analysis. IEEE Transactions on Engineering Management

Colla, V., Branca, T., Vannucci, M., Fornai, B., \& Amato, A. (2008, April 24-25). Quantitative sustainability assessment through key performance indicators in ULCOS project. In Proceedings of the 2nd International Seminar on Society \& Materials (SAM2). Nantes, France.

Colombo, C. R., \& Alves, A. C. (2017). Sustainability in engineering programs in a Portuguese Public University. Production, 27(spe), 1-16. http://dx.doi.org/10.1590/0103-6513.221416

Denuwara, N., Maijala, J., \& Hakovirta, M. (2019). Sustainability benefits of RFID technology in the apparel industry. Sustainability, 11(22), 6477. http://dx.doi.org/10.3390/su11226477.

Desore, A., \& Narula, S. A. (2018). An overview on corporate response towards sustainability issues in textile industry. Environment, Development and Sustainability, 20(4), 1439-1459. http://doi.org/10.1007/s10668-017-9949-1

Elhedhli, S., \& Merrik, R. (2012). Green supply chain network design to reduce carbon emissions. Transportation Research Part D, Transport and Environment, 17(5), 370-379. http://dx.doi.org/10.1016/j.trd.2012.02.002.

Elkington, J. (2004). Enter the triple bottom line. In: A. Henriques \& J. Richardson. The Triple Bottom Line - Does it all add up? (pp. 23-38). London: Earthscan.

Eren, S., Avinc, O., Saka, Z., \& Eren, H. A. (2018). Waterless bleaching of knitted cotton fabric using supercritical carbon dioxide fluid technology. Cellulose (London, England), 25(10), 6247-6267. http://dx.doi.org/10.1007/s10570-018-2004-z.

Fichtinger, J., Ries, J., Grosse, E., \& Baker, P. (2015). Assessing the environmental impact of integrated inventory and warehouse management. International Journal of Production Economics, 170, 717-729. http://dx.doi.org/10.1016/j.ijpe.2015.06.025.

Hou, G., Wang, Y., \& Xin, B. (2019). A coordinated strategy for sustainable supply chain management with product sustainability, environmental effect and social reputation. Journal of Cleaner Production, 228, 1143-1156. http://dx.doi.org/10.1016/j.jclepro.2019.04.096.

Hussain, T., \& Wahab, A. (2018). A critical review of the current water conservation practices in textile wet processing. Journal of Cleaner Production, 198, 806-819. http://dx.doi.org/10.1016/j.jclepro.2018.07.051.

lannone, R., Martino, G., Miranda, S., \& Riemma, S. (2015). Modeling fashion retail supply chain through causal loop diagram. IFACPapersOnLine, 48(3), 1290-1295.

Karaosman, H., Morales-Alonso, G., \& Brun, A. (2016). From a systematic literature review to a classification framework: sustainability integration in fashion operations. Sustainability, 9(30), 30. http://dx.doi.org/10.3390/su9010030.

Kates, R., Clark, W., Corell, R., Hall, M., Jaeger, C., Lowe, l., McCarthy, J., Schellnhuber, H., Bolin, B., Dickson, N., Faucheux, S., Gallopin, G. C., Grübler, A., Huntley, B., Jäger, J., Jodha, N. S., Kasperson, R. E., Mabogunje, A., Matson, P., Mooney, H., Moore, B. 3rd, O'Riordan, T., \& Svedlin, U. (2001). Environment and development. Sustainability science. Science, 292(5517), 641-642. http:// dx.doi.org/10.1126/science.1059386. PMid:11330321.

L'Inkiesta (2017). Trasportare merci in aereo? Emette CO2 cento volte più che farlo su grandi navi. Retrieved in 1 July 2019 , from www. linkiesta.it/it/article/2017/11/28/trasportare-merci-in-aereo-emette-co2-cento-volte-di-piu-che-farlo-su-/36330. 
Lewis, T. L., Park, H., Netravali, A. N., \& Trejo, H. X. (2017). Closing the loop: A scalable zero-waste model for apparel reuse and recycling. International Journal of Fashion Design. Technology and Education, 10(3), 353-362. http://dx.doi.org/10.1080/17543 266.2016.1263364.

Mota, B., Gomes, M. 1., Carvalho, A., \& Barbosa-Povoa, A. P. (2015). Towards supply chain sustainability: economic, environmental and social design and planning. Journal of Cleaner Production, 105, 14-27. http://dx.doi.org/10.1016/j.jclepro.2014.07.052.

Oelze, N., Brandenburg, M., Jansen, C., \& Warasthe, R. (2018). Applying sustainable supply chain management frameworks to two german case studies. IFAC-PapersOnLine, 51(30), 293-296.

Palak, G., Ekșioğlu, S. D., \& Geunes, J. (2014). Analyzing the impacts of carbon regulatory mechanisms on supplier and mode selection decisions: an application to a biofuel supply chain. International Journal of Production Economics, 154, 198-216. http://dx.doi. org/10.1016/j.jpe.2014.04.019.

Quattroruote (2017). Consumi ed emissioni: i dati aggiornati e tutto ciò che c’è da sapere. Retrieved in 1 July 2019, from https://www. quattroruote.it/news/eco_news/2010/01/15/consumi_ed_emissioni_per_capirne_di_più.html.

Radhakrishnan, S. (2017). Sustainable cotton production. In S. S. Muthu. Sustainable fibres and textiles (pp. 21-67).Cambridge: Woodhead Publishing.

Regione Emilia-Romagna. (2015). Indicazioni metodologiche per l'applicazione dei fattori di conversione al metodo di calcolo di cui alla DGR 967/2015 e alla DGR 1275/2015.Retrieved in 2020, June 17, from https://energia.regione.emilia-romagna.it/leggi-attibandi-1/norme-e-atti-amministrativi/certificazione-energetica/certificazione-energetica/DOC_INDIRIZZO_fattoridiconversione_2. pdf/@@download/file/DOC_INDIRIZZO_fattori\%20di\%20conversione_2.pdf

Rezaee, Z. (2018). Supply chain management and business sustainability synergy: A theoretical and integrated perspective. Sustainability, 10(1), 275. http://dx.doi.org/10.3390/su10010275.

Ricciardi, R. (2015). Repubblica.it. Retrieved in 2020, June 17, from https://www.repubblica.it/economia/2015/05/27/news/gas_luce_ bollette_eurostat-115374108/

Sanches, R. A., Pereira Marcicano, J. P., Barros de Held, M. S., Gama Guimarães, B. M., Seawright Alonso, R., Takamune, K. M., Duarte, A., \& Dedini, F. G. (2015). Organic cotton, lyocell and SPF: A comparative study. International Journal of Clothing Science and Technology, 27(5), 692-704. http://dx.doi.org/10.1108/1JCST-07-2014-0090.

Searcy, C. (2016). Measuring enterprise sustainability. Business Strategy and the Environment, 25(2), 120-133. http://dx.doi.org/10.1002/ bse. 1861.

Seuring, S., \& Müller, M. (2008). From a literature review to a conceptual framework for sustainable supply chain management. Journal of Cleaner Production, 16(15), 1699-1710. http://dx.doi.org/10.1016/j.jclepro.2008.04.020.

Seuring, S., \& Gold, S. (2013). Sustainability management beyond corporate boundaries: From stakeholders to performance. Journal of Cleaner Production, 56, 1-6. http://dx.doi.org/10.1016/j.jclepro.2012.11.033.

Shim, S., Kim, J., \& Na, Y. (2018). An exploratory study on up-cycling as the sustainable clothing life at home. Fashion and Textiles, 5(14), 14. http://dx.doi.org/10.1186/s40691-018-0129-1.

Singh, R. K., Murty, H. R., Gupta, S. K., \& Dikshit, A. K. (2009). An overview of sustainability assessment methodologies. Ecological Indicators, 9(2), 189-212. http://dx.doi.org/10.1016/j.ecolind.2008.05.011.

Tebaldi, L., Bigliardi, B., \& Bottani, E. (2018). Sustainable supply chain and innovation: A review of the recent literature. Sustainabilty, 10(11), 3946. http://dx.doi.org/10.3390/su10113946.

Teuteberg, F., \& Wittstruck, D. (2010). A systematic review of sustainable supply chain management. Multikonferenz Wirtschaftsinformatik, 2010, 203.

Tibben-Lembke, R. S., \& Rogers, D. S. (1998). The impact of reverse logistics on total cost of ownership. Journal of Marketing Theory and Practice, 6(4), 51-60. http://dx.doi.org/10.1080/10696679.1998.11501810.

Warasthe, R., \& Brandenburg, M. (2018). Sourcing organic cotton from african countries potentials and risks for the apparel industry supply chain. IFAC-PapersOnLine, 51(30), 297-301.

Winter, S., \& Lasch, R. (2016). Environmental and social criteria in supplier evaluation - Lessons from the fashion and apparel industry. Journal of Cleaner Production, 139, 175-190. http://dx.doi.org/10.1016/j.jclepro.2016.07.201.

Yang, S., Song, Y., Tong, S., \& Xiong, G. (2017). Sustainable retailing in the fashion industry: A systematic literature review. Sustainability, 9(7), 1266. http://dx.doi.org/10.3390/su9071266. 
Appendix A: list of input data for the application of the model and source

\begin{tabular}{|c|c|c|}
\hline Process & Input data & Source \\
\hline \multirow[t]{8}{*}{ Supply } & Types of raw materials used & Company \\
\hline & Number of suppliers & Company \\
\hline & $\begin{array}{l}\text { Types of transport means used and } \\
\text { related capacity }\end{array}$ & Company \\
\hline & $\begin{array}{l}\text { Amount of raw material purchased from } \\
\text { each supplier }\end{array}$ & Company \\
\hline & Unitary cost of each raw material & Company \\
\hline & Location of each supplier & Company \\
\hline & $\begin{array}{l}\text { Unitary cost of each type of transport } \\
\text { means }\end{array}$ & $\begin{array}{l}\text { Company; specialized websites (e.g. www.quattroruote.it for road transport, } \\
\text { http://timeforchange.org/co2-emissions-shipping-goods for sea transport; www. } \\
\text { linkiesta.it/it/article/2017/11/28/trasportare-merci-in-aereo-emette-co2-cento- } \\
\text { volte-di-piu-che-farlo-su-/36330/ for air transport); Italian Ministry for Transports }\end{array}$ \\
\hline & $\begin{array}{l}\text { Unitary emissions of each type of } \\
\text { transport means }\end{array}$ & $\begin{array}{l}\text { Company; specialized websites (e.g. www.quattroruote.it for road transport, } \\
\text { http://timeforchange.org/co2-emissions-shipping-goods for sea transport; www. } \\
\text { linkiesta.it/it/article/2017/11/28/trasportare-merci-in-aereo-emette-co2-cento- } \\
\text { volte-di-piu-che-farlo-su-/36330/ for air transport); ltalian Ministry for Transports }\end{array}$ \\
\hline \multirow[t]{6}{*}{$\begin{array}{l}\text { In-house } \\
\text { production }\end{array}$} & Number of product categories & Company \\
\hline & Number of production process & Company \\
\hline & $\begin{array}{l}\text { Number of units produced per product } \\
\text { category }\end{array}$ & Company \\
\hline & $\begin{array}{l}\text { Unitary production cost per product } \\
\text { category }\end{array}$ & Company \\
\hline & $\begin{array}{l}\text { Unitary energy consumption of the } \\
\text { production process }\end{array}$ & Company \\
\hline & $\begin{array}{l}\text { Volume dedicated to each production } \\
\text { process }\end{array}$ & Company \\
\hline \multirow[t]{9}{*}{$\begin{array}{l}\text { Outsourced } \\
\text { production }\end{array}$} & Number of production plants & Company \\
\hline & Location of each production plant & Company \\
\hline & $\begin{array}{l}\text { Amount of raw materials shipped to each } \\
\text { production plant }\end{array}$ & Company \\
\hline & $\begin{array}{l}\text { Amount of finished products } \\
\text { manufactured at each production plant }\end{array}$ & Company \\
\hline & $\begin{array}{l}\text { Types of transport means used and } \\
\text { related capacity }\end{array}$ & Company \\
\hline & Unitary cost per transport means & $\begin{array}{l}\text { Company; specialized websites (e.g. www.quattroruote.it for road transport, } \\
\text { http://timeforchange.org/co2-emissions-shipping-goods for sea transport; www. } \\
\text { linkiesta.it/it/article/2017/11/28/trasportare-merci-in-aereo-emette-co2-cento- } \\
\text { volte-di-piu-che-farlo-su-/36330/ for air transport); Italian Ministry for Transports }\end{array}$ \\
\hline & Unitary emissions per transport means & $\begin{array}{l}\text { Company; specialized websites (e.g. www.quattroruote.it for road transport, } \\
\text { http://timeforchange.org/co2-emissions-shipping-goods for sea transport; www. } \\
\text { linkiesta.it/it/article/2017/11/28/trasportare-merci-in-aereo-emette-co2-cento- } \\
\text { volte-di-piu-che-farlo-su-/36330/ for air transport); Italian Ministry for Transports }\end{array}$ \\
\hline & $\begin{array}{l}\text { Amount of product purchased from } \\
\text { production plant }\end{array}$ & Company \\
\hline & Unitary cost of purchased items & Company \\
\hline \multirow[t]{5}{*}{ Distribution } & $\begin{array}{l}\text { Number and location of the destinations } \\
\text { to be reached }\end{array}$ & Company \\
\hline & $\begin{array}{l}\text { Types of transport means used and } \\
\text { related capacity }\end{array}$ & Company \\
\hline & $\begin{array}{l}\text { Amount of product requested by each } \\
\text { destination }\end{array}$ & Company \\
\hline & Unitary emission per transport means & $\begin{array}{l}\text { Company; specialized websites (e.g. www.quattroruote.it for road transport, } \\
\text { http://timeforchange.org/co2-emissions-shipping-goods for sea transport; www. } \\
\text { linkiesta.it/it/article/2017/11/28/trasportare-merci-in-aereo-emette-co2-cento- } \\
\text { volte-di-piu-che-farlo-su-/36330/ for air transport); ltalian Ministry for Transports }\end{array}$ \\
\hline & $\begin{array}{l}\text { Unitary transport cost per transport } \\
\text { means }\end{array}$ & $\begin{array}{l}\text { Company; specialized websites (e.g. www.quattroruote.it for road transport, } \\
\text { http://timeforchange.org/co2-emissions-shipping-goods for sea transport; www. } \\
\text { linkiesta.it/it/article/2017/11/28/trasportare-merci-in-aereo-emette-co2-cento- } \\
\text { volte-di-piu-che-farlo-su-/36330/ for air transport); Italian Ministry for Transports }\end{array}$ \\
\hline \multirow[t]{2}{*}{ Warehousing } & Unitary cost of goods storage & Company \\
\hline & Warehouse area & Company \\
\hline
\end{tabular}


Appendix A: Continued...

\begin{tabular}{|c|c|c|}
\hline Process & Input data & Source \\
\hline & Unitary electricity cost & Company; Ricciardi (2015) \\
\hline & Lighting factor & Company; Fichtinger et al. (2015) \\
\hline & Heating/cooling factor & Company; Fichtinger et al. (2015) \\
\hline & $\begin{array}{l}\text { Types of fixed and mobile material } \\
\text { handling equipment used }\end{array}$ & Company \\
\hline & Working hours per year & Company \\
\hline & $\begin{array}{l}\text { Unitary energy consumption of fixed and } \\
\text { mobile material handling equipment }\end{array}$ & Company \\
\hline & Energy conversion factors & Regione Emilia-Romagna (2015) \\
\hline \multirow[t]{8}{*}{ Reverse logistics } & Number of collection centers & Company \\
\hline & $\begin{array}{l}\text { Transport means used and related } \\
\text { capacity }\end{array}$ & Company \\
\hline & $\begin{array}{l}\text { Amount of product treated in the process } \\
\text { per product category }\end{array}$ & Company \\
\hline & $\begin{array}{l}\text { Unitary emission of each process } \\
\text { (including disposal) }\end{array}$ & Company \\
\hline & $\begin{array}{l}\text { Unitary cost of each recovery process } \\
\text { (including disposal) }\end{array}$ & Company \\
\hline & $\begin{array}{l}\text { Product categories treated in the various } \\
\text { recovery processes }\end{array}$ & Company \\
\hline & Unitary cost of each transport means & $\begin{array}{l}\text { Company; specialized websites (e.g. www.quattroruote.it for road transport, } \\
\text { http://timeforchange.org/co2-emissions-shipping-goods for sea transport; www. } \\
\text { linkiesta.it/it/article/2017/11/28/trasportare-merci-in-aereo-emette-co2-cento- } \\
\text { volte-di-piu-che-farlo-su-/36330/ for air transport); 1talian Ministry for Transports }\end{array}$ \\
\hline & $\begin{array}{l}\text { Unitary emissions of each transport } \\
\text { means }\end{array}$ & $\begin{array}{l}\text { Company; specialized websites (e.g. www.quattroruote.it for road transport, } \\
\text { http://timeforchange.org/co2-emissions-shipping-goods for sea transport; www. } \\
\text { linkiesta.it/it/article/2017/11/28/trasportare-merci-in-aereo-emette-co2-cento- } \\
\text { volte-di-piu-che-farlo-su-/36330/ for air transport); ltalian Ministry for Transports }\end{array}$ \\
\hline
\end{tabular}

